\title{
Erratum to: Statistical Modeling of Thermal Properties of Biobased Compostable Gloves Developed from Sustainable Polymer
}

\author{
Muhammad Maqsood* and Gunnar Seide \\ Aachen Maastricht Institute for Biobased Materials, Maastricht University, Urmonderbaan 22, 6167 RD Geleen, Netherlands
}

CThe Author(s) 2018

Erratum to: Fibers and Polymers 2018, Vol.19, No.5, 1094-1101

https://doi.org/10.1007/s12221-018-1126-0

The article Statistical Modeling of Thermal Properties of Biobased Compostable Gloves Developed from Sustainable Polymer, written by Muhammad Maqsood and Gunnar Seide, was mistakenly originally published without open access. After publication in volume 19, issue 5, page 1049-1101 this was corrected and the article was made an open access publication. Therefore, the copyright of the article has been changed to (C) The Author(s) 2018 and the article is forthwith distributed under the terms of the Creative Commons Attribution 4.0 International License (http://creativecommons.org/licenses/by/4.0/), which permits use, duplication, adaptation, distribution and reproduction in any medium or format, as long as you give appropriate credit to the original author(s) and the source, provide a link to the Creative Commons license, and indicate if changes were made.

The original article has been corrected.

Open Access This article is distributed under the terms of the Creative Commons Attribution 4.0 International License (http:// creativecommons.org/licenses/by/4.0/), which permits unrestricted use, distribution, and reproduction in any medium, provided you give appropriate credit to the original author(s) and the source, provide a link to the Creative Commons license, and indicate if changes were made. 